\title{
The nutritive value of dried red clover as a supplement for perennial ryegrass hay
}

\author{
By G. MOSELEY \\ Welsh Plant Breeding Station, Plas Gogerddan, Aberystwyth
}

(Received I7 October 1973-Accepted 16 April 1974)

\begin{abstract}
I. A low-digestibility ryegrass hay was fed to sheep and the effect of supplementation with dried red clover on animal production and digestion was examined. Comparisons were made using other supplements containing $(a)$ barley (isoenergetic with clover supplement), $(b)$ barley and decorticated groundnut meal (isoenergetic and isonitrogenous with clover supplement), (c) barley, groundnut meal and mineral salts (containing an equivalent level of digestible energy, apparently digestible crude protein and minerals to those of the clover supplement).

2. Dry matter intake, digestibility of organic matter and live-weight gain were higher with clover supplemented hay than with hay alone, and the live-weight gain response to clover supplementation was comparable with the concentrate diet (supplement $c$ ), which supplied an equivalent level of digestible energy, crude protein and minerals.

3. The utilization of digestible energy for live-weight gain was significantly higher $(P<0.05)$ for clover than for hay, hay plus barley, and hay plus barley and groundnut meal. The utilization of the clover - hay mixture was similar to that of the hay plus concentrates and minerals and tended to be higher than that of the concentrate diet without minerals, although the difference was not significant $(P<0.05)$.

4. There was no significant difference between hay and clover diets in the proportions of volatile fatty acids found in the rumen, although there was a shift from acetate to butyrate production with the two diets containing groundnut meal.

5. The apparent digestibility of nitrogen for both hay and clover was low, but intake and retention was markedly increased with clover.

6. The intake and retention for all the minerals studied was better for the clover-supplemented hay and all-clover diets than for the hay diet, and the availability of sodium, potassium, magnesium, calcium and phosphorus was higher. The availability and retention of $\mathrm{Na}, \mathrm{K}$ and $\mathrm{Mg}$ with the clover-supplemented hay diet were slightly lower than the mineral-supplemented diet, while those of $\mathrm{Ca}$ and $\mathrm{P}$ were higher.
\end{abstract}

The nutritive value of white clover as a feedstuff for ruminants has received much attention in recent years. Many authors, e.g. Sinclair, Clarke \& Filmer (I956), Grimes, Watkin \& Gallagher (1967), Ulyatt (1969), Rattray \& Joyce (1970a) and Lancashire (I97I), have shown that grass-clover or all-clover diets are of higher quality than allgrass diets, as indicated by the increased live-weight gains of young ruminants. Such increased animal production has been attributed to various factors, e.g. differences in herbage morphology (Evans, r964), herbage utilization (Joyce \& Newth, I967, Rattray \& Joyce, 1969), herbage carbohydrate composition (Bailey, r964), and molar proportions of rumen volatile fatty acids (Johns, Ulyatt \& Glenday, I963). Many of these authors report a higher dry-matter intake for clover than for grass, which in itself may account for a significant part of the increased live-weight gain, but Ulyatt (197I) and Rattray \& Joyce (1969, I970a, $b, c)$ argue that there is also a better retention and utilization of energy, nitrogen and minerals with clover diets.

Previous work at this Station has shown the extent to which high-quality, driedgrass diets can be improved for cattle (Miles, Walters \& Evans, 1969), and for sheep (Patil, I969), by supplementing with red clover. In view of the marked responses 
obtained, the experiments below attempt to delineate the contribution of the nutritional components of the clover to changes in animal production.

\section{MATERIALS AND METHODS}

Animals and diets. Twenty-four I-year-old Clun Forest wethers were selected from a flock for uniformity of body-weight. The animals were dosed with Thibenzole (2-(thiazol-4-yl)benzimidazole) (Merck, Sharp \& Dohme Ltd, Hoddesdon, Herts) and placed on a pre-experimental regimen of $\mathrm{S}_{23}$ hay given $a d$ lib. for $\mathrm{I}_{4} \mathrm{~d}$, during which time the voluntary intake was estimated. Six groups of four animals were randomly selected and allocated to the treatments described below.

The wethers were weighed following a $24 \mathrm{~h}$ fast, and housed individually in metabolism crates fitted with faeces and urine separators. The experimental diets were given for $30 \mathrm{~d}$ and the food intake was measured over the whole of this period. The daily feed was split into two equal portions and given at 09.00 and 16.30 hours. The $\mathrm{S} 23$ ryegrass hay was always given in $15 \%$ excess of voluntary intake and refusals were removed daily before the morning feed. Urine and faeces were collected over the final ro d.

At the end of the experimental period rumen fluid samples were obtained by stomach tube $3 \mathrm{~h}$ after the final morning feed and were immediately frozen at $-20^{\circ}$. The animals were again weighed following a $24 \mathrm{~h}$ fast.

Hay was made from a regrowth of $\mathrm{S}_{23}$ perennial ryegrass which had been put up for conservation in early May following grazing. The sward was in its second harvest year and contained less than $10 \%$ weeds and unsown grasses. It was cut for hay during July I97 I, 3 weeks after heading, and was chopped to a staple length of $30 \mathrm{~mm}$ for feeding.

First growth Sabtoron broad red clover, containing less than $15 \%$ weeds and unsown grasses, was cut in July $197 \mathrm{I}$ in its first harvest year at the $75 \%$ flowering stage and artificially dried in a Templewood low-temperature grass drier (Templewood conveyor drier, Mark 2, Templewood Engineering Co. Ltd, Slough). Because of its friable consistency, the clover was offered without further preparation.

All supplementary concentrates were hammer-milled and pelleted and given twice daily with the hay.

There were six experimental groups, of which groups $x-5$ received $S 23$ hay ad lib. Group I received $\mathrm{S}_{23}$ hay only, and group 6 received Sabtoron red clover only, offered ad lib. Groups 2, 3, 4 and 5 received the following supplement to the hay (g/d): group 2, 640 dried red clover; group 3, 380 barley, to provide a digestible energy intake equivalent to the clover supplement; group 4, 297 barley and 83 decorticated groundnut meal, to provide an intake of digestible energy and crude protein equivalent to the clover supplement; group 5 , as group 4 , but with a mineral mixture containing (g): $2.5 \mathrm{Na}_{2} \mathrm{HPO}_{4},{ }_{4} \cdot 5 \mathrm{CaO},{ }_{13} \cdot \mathrm{MgSO}_{4} .7 \mathrm{H}_{2} \mathrm{O}, 0.0015 \mathrm{CuSO}_{4} \cdot{ }_{5} \mathrm{H}_{2} \mathrm{O}$. This supplement approximately equated with the content of digestible energy, crude protein and minerals in the group 2 clover supplement, as estimated by chemical analysis. 
Table I. Chemical composition of the dry matter $(\mathrm{g} / \mathrm{kg})$ of the diets given to sheep

\begin{tabular}{|c|c|c|c|c|c|c|c|c|c|c|}
\hline & $\begin{array}{c}\text { In } \\
\text { vitro } \\
\text { digesti- } \\
\text { bility } \\
\text { (DOMD) }\end{array}$ & $\begin{array}{l}\text { Neutral- } \\
\text { deter- } \\
\text { gent } \\
\text { fibre }\end{array}$ & $\begin{array}{l}\text { Nitro- } \\
\text { gen }\end{array}$ & Calcium & $\begin{array}{c}\text { Mag- } \\
\text { nesium }\end{array}$ & Sodium & $\begin{array}{l}\text { Potas- } \\
\text { sium }\end{array}$ & $\begin{array}{l}\text { Phos- } \\
\text { phorus }\end{array}$ & $\begin{array}{l}\text { Sul- } \\
\text { phur }\end{array}$ & Copper \\
\hline $\mathrm{S}_{23} \mathrm{Hay}$ & 0.571 & 700 & 9.4 & 3.96 & I. 38 & $x \cdot 62$ & $16 \cdot 72$ & $2 \cdot 42$ & $I \cdot 5 I$ & 3.7 \\
\hline Red clover & 0.516 & 528 & $23 \cdot 4$ & $17 \cdot 75$ & $3 \cdot 45$ & 0.89 & 19.40 & $2 \cdot 77$ & $2 \cdot 79$ & I I 0 \\
\hline Supplement 3 & & & $18 \cdot 7$ & $I \cdot 19$ & $1 \cdot 33$ & 0.39 & $4 \cdot 45$ & 0.63 & 0.64 & $5 \cdot 3$ \\
\hline Supplement 4 & & & 30.3 & $1 \cdot 52$ & 1.72 & 0.49 & $6 \cdot 15$ & $\mathrm{I} \cdot 75$ & 0.66 & 6.5 \\
\hline Supplement 5 & & & 30.8 & $9 \cdot 00$ & $5 \cdot 10$ & $1 \cdot 37$ & 6.08 & 3.07 & $3 \cdot 26$ & $8 \cdot 5$ \\
\hline
\end{tabular}

Supplement 3, barley; supplement 4, barley and decorticated groundnut meal; supplement 5 , barley, decorticated groundnut meal and mineral mixture $\left(\mathrm{Na}_{2} \mathrm{HPO}_{3}, \mathrm{CaO}, \mathrm{MgSO}_{4} \cdot 7 \mathrm{H}_{2} \mathrm{O}\right.$ and $\left.\mathrm{CuSO}_{4} \cdot{ }_{5} \mathrm{H}_{2} \mathrm{O}\right)$.

Analyses. Food and faeces were analysed for dry matter, organic matter and gross energy, and the digestibility of organic matter in the dry matter of the diets (DOMD) was estimated as:

$$
\text { DOMD }=\frac{\text { Organic matter intake }- \text { faecal organic matter }}{\text { dry matter intake }} .
$$

In vitro digestibility was determined by the technique of Tilley $\&$ Terry (1963) and neutral-detergent fibre was determined by the method of van Soest (1963).

Food, faeces and urine were analysed for $\mathrm{N}$ by the macro-Kjeldahl method, for calcium and magnesium by atomic absorption spectrophotometry, for sodium and potassium by flame photometry, and for phosphorus by colorimetry using the ammonium vanadate method (Cavell, 1955). Fresh faeces were used for the $\mathrm{N}$ determination, and the energy value of urine was measured using the technique of Nijkamp (I965).

The volatile fatty acid composition of rumen fluid samples was determined by gasliquid chromatography using a column of Carbowax 20M (Union Carbide Ltd) with nitrogen carrier gas and flame ionization detector (Panchromatograph, Pye Unicam), following steam distillation with acidified $\mathrm{MgSO}_{4}$ and neutralization with $\mathrm{NaOH}$.

\section{RESULTS}

Analysis of the diets (Table I) showed higher concentrations of all mineral elements in red clover than in $\mathrm{S}_{23}$ hay, with the exception of $\mathrm{Na}$, which was still adequate in clover according to published requirements (Agricultural Research Council, I965). The in vitro DOMD of both $\mathrm{S}_{23}$ hay and red clover was low, and neutral-detergent fibre fraction was $33 \%$ greater in the hay. The concentration of $\mathrm{Ca}$ in red clover was more than five times the estimated requirement, and consequently the amount used for the mineral supplement given to group 5 was limited to $50 \%$ of this.

Supplementation of $\mathrm{S}_{23}$ hay with red clover in group 2 increased the DOMD of the ration 0.016 and 0.065 units above the hay and clover constituents respectively (Table 2), the DOMD of the mixture being significantly higher $(P<0.002)$ by 0.042 units than the arithmetic mean for the two components. The addition of barley in group 3 significantly increased $(P<0.0 I)$ the DOMD, by approximately 0.1 units 
Table 2. Intake of dry matter $(\mathrm{g} / \mathrm{d})$ and dietary digestible organic matter (DOMD, $\mathrm{g} / \mathrm{kg}$ ) of groups of sheep given hay or clover diets with or without supplements

\begin{tabular}{|c|c|c|c|c|c|}
\hline \multicolumn{6}{|c|}{ (Mean values for four animals/group) } \\
\hline Groups & Diet* & $\begin{array}{c}\text { Dry } \\
\text { matter } \\
\text { intake } \\
\text { of } \\
\text { hay }\end{array}$ & $\begin{array}{c}\text { Total } \\
\text { dry } \\
\text { matter } \\
\text { intake }\end{array}$ & DOMD & $\begin{array}{l}\text { Intake } \\
\text { of } \\
\text { digestible } \\
\text { organic } \\
\text { matter } \\
(\mathrm{g} / \mathrm{d})\end{array}$ \\
\hline $\mathbf{r}$ & Hay & $7 \circ 7$ & 707 & 0.575 & $3^{62}$ \\
\hline 2 & Hay + clover & 499 & 1049 & 0.591 & 559 \\
\hline 3 & Hay + barley & 554 & 874 & 0.684 & 536 \\
\hline 4 & Hay + barley + DGM & 595 & 921 & 0.705 & 582 \\
\hline 5 & Hay + barley + DGM + minerals & 698 & 1042 & 0.667 & 625 \\
\hline 6 & Clover & - & 1257 & 0.526 & 596 \\
\hline \multicolumn{2}{|c|}{$\mathrm{SE}$ of mean } & 73 & I I9 & 0.015 & 34 \\
\hline
\end{tabular}

DGM, decorticated groundnut meal.

* For details see p. 318 .

above the hay level, but the addition of groundnut meal in group 4 did not significantly increase the digestibility of the ration over that of group 3 . The addition of minerals in group 5 , however, significantly depressed $(P<0.01)$ DOMD compared with the group 4 diet.

The total dry matter intake of group 2 was $48 \%$ higher $(P<0.002)$ than that of group I receiving hay alone, while that of group 6 was $78 \%$ higher $(P<0.00 \mathrm{I})$ than that of group I. Supplementation of hay with concentrates in groups 3,4 and 5 produced increments of 24,30 and $47 \%$ respectively $(P<0.002)$, in the dry matter intakes above the group $\mathrm{I}$ level.

In the daily energy balance and utilization shown in Table 3, the digestible energy intakes of the groups given clover-supplemented hay and clover ( 2 and 6 ) were $60 \%$ $(P<0.001)$ and $90 \%(P<0.001)$ higher respectively than that of group 1 . There was an increase in digestible energy intake in groups 3,4 and 5 with increments of 56 , 73 and $88 \%$ respectively above that of group I. The proportion of digestible energy lost in urine was fairly constant for groups $1-5$, while that for group 6 was significantly higher $(P<0.00 r)$ and almost doubled at $4.4 \%$. The digestibility of energy maintained the same ranking as DOMD, except that for group I which was relatively lower, and that for group 6 , which was relatively higher. The group 2 diet was again higher in digestibility of energy than its components as fed to groups I and 6, but not significantly so.

The daily live-weight gains shown in Table 3 indicate a marked increase with clover supplementation of hay in group 2 compared with those of group I. Although this did not achieve the same daily live-weight gain as group 5 (concentrates plus minerals) the response was approximately equal for live-weight gain/unit energy consumed per unit metabolic body-weight. The all-clover diet was superior to the other diets in daily live-weight gain and live-weight gain/unit digestible energy consumed.

The relative proportions of VFA found in the rumen fluid (Table 4) were not significantly different between the hay and clover diets of groups I, 2 and 6. Groups 4 
Vol. 32

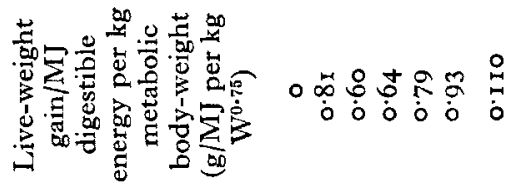

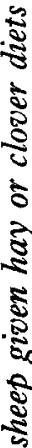
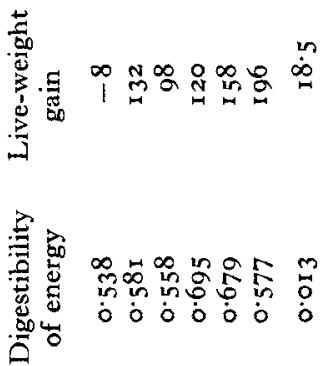

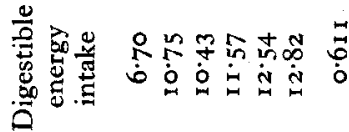

$\frac{\sqrt{0}}{8}$

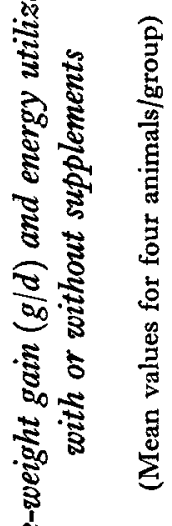

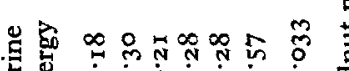

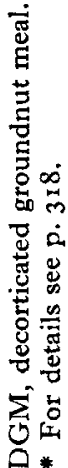

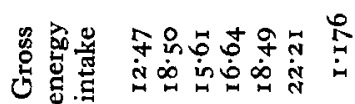

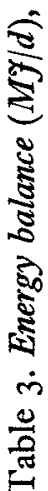
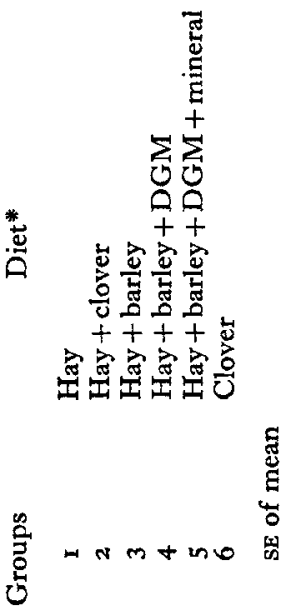
Table 4. Molar percentage of rumen volatile fatty acids in sheep given hay or clover diets with or without supplements

\begin{tabular}{|c|c|c|c|c|c|c|}
\hline \multicolumn{7}{|c|}{ (Mean values for four animals/group) } \\
\hline Groups & Diet* & Acetate & Propionate & Butyrate & Valerate & Isovalerate \\
\hline I & & 60.5 & 244 & $11 \cdot 3$ & $1 \cdot 5$ & $2 \cdot 3$ \\
\hline 2 & Hay + clover & $62 \cdot 2$ & 22.4 & $12 \cdot 6$ & 0.6 & $1 \cdot 5$ \\
\hline 3 & Hay + barley & $6 I \cdot 9$ & $16 \cdot 5$ & $19 \cdot 5$ & 0.9 & $I \cdot \mathbf{I}$ \\
\hline 4 & Hay + barley + DG.M & $53 \cdot 3$ & $21 \cdot 4$ & $21 \cdot 0$ & $\mathrm{I} \cdot 9$ & $2 \cdot 4$ \\
\hline 5 & $\begin{array}{l}\text { Hay + barley }+ \text { DGM } \\
+ \text { minerals }\end{array}$ & 57.4 & $20 \cdot 1$ & $19 \cdot 3$ & 0.7 & $2 \cdot 6$ \\
\hline 6 & Clover & $64 \cdot 2$ & $2 I \cdot 0$ & II $\cdot 0$ & $I \cdot I$ & $2 \cdot 7$ \\
\hline \multicolumn{2}{|c|}{$\mathrm{SE}$ of mean } & $\mathbf{1} \cdot 69$ & $\mathbf{I} \cdot 3 \mathbf{1}$ & $\mathrm{r} \cdot 62$ & 0.23 & 0.56 \\
\hline
\end{tabular}

Table 5. Daily nitrogen balance $(g / d)$ and $N$ utilization in sheep given hay or clover diets with or without supplements

\begin{tabular}{|c|c|c|c|c|c|}
\hline \multicolumn{6}{|c|}{ (Mean values for four animals/group) } \\
\hline Groups & Diet* & $\mathrm{N}$ intake & Faecal N & Urinary $\mathrm{N}$ & $N$ retention \\
\hline $\mathbf{I}$ & HIay & $6 \cdot 65$ & $4 \cdot 60$ & I 997 & 0.08 \\
\hline 2 & Hay + clover & $17 \cdot 39$ & 10.65 & $2 \cdot 83$ & $3 \cdot 91$ \\
\hline 3 & Hay + barley & II.16 & $5 \cdot 91$ & $2 \cdot 39$ & $2 \cdot 86$ \\
\hline 4 & Hay + barley + DGM & $16 \cdot 46$ & 6.73 & $4 \cdot 62$ & $4^{\cdot 11} 1$ \\
\hline $\begin{array}{l}4 \\
5 \\
6\end{array}$ & $\begin{array}{l}\text { Ilay + barley + DGM + minerals } \\
\text { Clover }\end{array}$ & $\begin{array}{l}17 \cdot 13 \\
20 \cdot 78\end{array}$ & $\begin{array}{r}6 \cdot 71 \\
16 \cdot 17\end{array}$ & $\begin{array}{l}4 \cdot 32 \\
5.98\end{array}$ & $\begin{array}{l}7.09 \\
7.64\end{array}$ \\
\hline \multicolumn{2}{|c|}{ SE of mean } & 0.65 & 0.59 & 0.41 & 0.21 \\
\hline
\end{tabular}

DGM, decorticated groundnut meal.

* For details see p. 3 I 8 .

and 5, which were supplemented with groundnut meal, had a lower proportion of acetate and a higher proportion of butyrate. In group 3 , the fermentation appeared to favour butyrate rather than propionate, with acetate production being similar to that of group I.

Intake, apparent digestibility and retention of $\mathrm{N}$ were low with the hay diet (Table 5) but wcre significantly increased $(P<0.00 \mathrm{I})$ with all other diets. The addition of minerals in the group 5 diet gave a higher digestibility and significantly higher retention $(P<0.001)$ than the group 4 diet, which had a similar $\mathrm{N}$ intake. The all-clover diet given to group 6 had the highest $\mathrm{N}$ intake and, although the digestibility was low, the retention was significantly higher $(P<0.001)$ than that in other groups.

The intake of all the minerals studied was improved by clover supplementation of grass (Table 6). The availability of $\mathrm{Ca}$ and $\mathrm{P}$ was significantly increased $(P<0.00 \mathrm{r})$, and in every instance the retention of minerals was improved.

The availability of minerals in the mineral-supplemented diet 5 was higher than the clover-hay diet for $\mathrm{Na}, \mathrm{K}, \mathrm{Mg}$, Ca but lower for $\mathrm{P}$. The intake and retention of $\mathrm{K}$, $\mathrm{Mg}$, Ca and $\mathrm{P}$ was higher for the all-clover diet, but was lower for $\mathrm{Na}$ than for all other diets. 
Table 6. Daily mineral balance $(\mathrm{g} / \mathrm{d})$ and utilization in sheep given hay or clover diets with or without supplements

\begin{tabular}{|c|c|c|c|c|c|c|c|}
\hline \multirow{2}{*}{ Groups* } & \multicolumn{4}{|c|}{ (Mean values for four animals/group) } & \multirow[b]{2}{*}{5} & \multirow[b]{2}{*}{6} & \multirow[b]{2}{*}{ SE } \\
\hline & I & 2 & 3 & 4 & & & \\
\hline \multicolumn{8}{|c|}{ Sodium } \\
\hline $\begin{array}{l}\text { Intake } \\
\text { Apparent availability }(\%) \\
\text { Retention } \\
\text { Retained }(\%) \text { : available }\end{array}$ & $\begin{array}{l}I \cdot 145 \\
57 \\
0 \cdot 446 \\
68\end{array}$ & $\begin{array}{l}I \cdot 269 \\
58 \\
0 \cdot 546 \\
74\end{array}$ & $\begin{array}{l}1 \cdot 022 \\
77 \\
0.670 \\
91\end{array}$ & $\begin{array}{l}I \cdot I 23 \\
66 \\
0.634 \\
85\end{array}$ & $\begin{array}{l}1 \cdot 602 \\
68 \\
0.637 \\
58\end{array}$ & $\begin{array}{l}x \cdot 077 \\
63 \\
0 \cdot 395 \\
5^{8}\end{array}$ & $\begin{array}{l}0.109 \\
4.2 \\
0.094\end{array}$ \\
\hline \multicolumn{8}{|c|}{ Potassium } \\
\hline Intake & $1 \mathrm{I} \cdot 82$ & $19 \cdot 03$ & 10.69 & I I 95 & $13 \cdot 76$ & $22 \cdot 23$ & $1 \cdot 35$ \\
\hline Apparent availability (\%) & 71 & 71 & 65 & $5^{8}$ & 80 & $8 I$ & $4 \cdot 9$ \\
\hline Retention & 0.32 & $I \cdot 3 I$ & -0.18 & 0.45 & $I \cdot 43$ & 0.69 & 0.94 \\
\hline Retained $(\%)$ : available & 4 & 10 & -2 & I6 & I3 & 4 & \\
\hline \multicolumn{8}{|c|}{ Magnesium } \\
\hline Intake & 0.975 & $2 \cdot 598$ & $\mathrm{I} \cdot \mathrm{I} 89$ & $\mathbf{I} \cdot 3^{8} 3$ & $2 \cdot 718$ & $3 \cdot 954$ & 0.173 \\
\hline Apparent availability (\%) & & 30 & 38 & 38 & 37.00 & 37 & $6 \cdot 1$ \\
\hline $\begin{array}{l}\text { Retention } \\
\text { Retained }(\%) \text { : available }\end{array}$ & $\frac{0.219}{73}$ & $\begin{array}{l}0.6 \text { Io } \\
78\end{array}$ & $68^{0.306}$ & $7^{0.410}$ & $\begin{array}{l}0.769 \\
77\end{array}$ & $8_{3}^{I \cdot 295}$ & 0.168 \\
\hline \multicolumn{8}{|c|}{ Calcium } \\
\hline Intake & $2 \cdot 799$ & $\mathrm{II} \cdot 77 \mathrm{I}$ & $2 \cdot 603$ & $2 \cdot 849$ & $5.86 \mathrm{I}$ & $20 \cdot 285$ & 0.809 \\
\hline Apparent availability $(\%)$ & -14 & Io & -0.3 & 3 & I7 & 9 & 3.9 \\
\hline Retention & $-0.45^{2}$ & I. I99 & -0.025 & 0.069 & 0.948 & $I \cdot 808$ & 0.330 \\
\hline Retained $(\%)$ : available & - ve & 98 & - ve & 78 & 98 & 97 & \\
\hline \multicolumn{8}{|c|}{ Phosphorus } \\
\hline Intake & I'7II & $2 \cdot 736$ & $\mathrm{I} \cdot 542$ & $2 \cdot 011$ & $2 \cdot 746$ & $3 \cdot 175$ & 0.194 \\
\hline Apparent availability (\%) & $3 \mathrm{I}$ & 53 & & 39 & 39 & & $4 \cdot 2$ \\
\hline $\begin{array}{l}\text { Retention } \\
\text { Retained }(\%) \text { : available }\end{array}$ & $\begin{array}{l}0.524 \\
99\end{array}$ & $\begin{array}{l}\mathbf{I} \cdot 427 \\
99\end{array}$ & $\begin{array}{l}\text { O.1 I } 7 \\
94\end{array}$ & $\begin{array}{l}0.572 \\
97\end{array}$ & $\begin{array}{l}I \cdot 075 \\
99\end{array}$ & $\begin{array}{l}1 \cdot 760 \\
99\end{array}$ & $0 \cdot 245$ \\
\hline
\end{tabular}

* Group I, hay; group 2, hay + clover; group 3, hay + barley; group 4, hay + barley + decorticated groundnut meal; group 5, hay + barley + decorticated groundnut meal + minerals; group 6, clover; details see p. 318 .

\section{DISCUSSION}

Two of the most striking observations in this experiment were the increased dry matter intakes and live-weight gains of animals fed the all-clover and clover-grass diets compared to those fed all-grass and grass-concentrate diets. The results for the grass and clover diets were in agreement with those of Rattray \& Joyce (I969), who also found better intake and live-weight gains from sheep given frozen white clover compared with perennial ryegrass, and Ulyatt (I97I) who grazed sheep on swards of white clover, perennial ryegrass and short-rotation ryegrass.

Bailey (I964) and Evans (1964), suggested that because short-rotation ryegrass contained less structural carbohydrate than perennial ryegrass, and had a lower leaf strength, it was more rapidly broken down in the rumen, had a faster rate of passage through the gut and, therefore, a higher intake. The results of Ulyatt (I97I) supported this hypothesis when he showed that the retention time of organic matter in the rumen was greater for perennial than for either short-rotation ryegrass or clover, and that up 
to $49 \%$ of the variation in organic matter intake could be accounted for by variations in rumen organic matter retention time.

The dried red clover used in this experiment was extremely friable and had a much lower structural integrity than the $\mathrm{S} 23$ hay. This suggests that a more rapid physical breakdown of clover might occur during the initial digestive processes to provide a greater surface area for digestion in the rumen.

Chemical analysis of the diets showed that the neutral-detergent fibre fraction of grass was $320 \mathrm{~g} / \mathrm{kg}$ higher than that of clover (Table I), thus indicating a higher proportion of indigestible and less readily fermentable material in grass.

From the hypotheses of Bailey (1964), Evans (1964) and Ulyatt (1971), both these differences should account for a higher rate of passage through the gut, and therefore, the observed higher intake with the clover diets.

The conservation of clover by heat drying would tend to bring about a denaturation of protein and this was evident in the very low digestibility of $\mathrm{N}$ in the clover diets. The presence of denatured protein would tend to increase the neutral-detergent fibre fraction and decrease the amount of readily fermentable material available to rumen micro-organisms. Thus the neutral-detergent fibre fraction $(530 \mathrm{~g} / \mathrm{kg})$ of clover would be even smaller if the clover had not been conserved by heating. Rattray \& Joyce (1969) showed that when white clover and perennial ryegrass were given in a 50:50 mixture the DOMD was a mean of the components, while in this experiment the DOMD was 0.042 units above the arithmetic mean. It is not clear whether this apparently synergistic effect on DOMD was brought about by an increase in grass digestibility following an increase in crude protein intake with clover supplementation or whether it is due to some other change in rumen conditions which favoured the breakdown of the less digestible fractions of the diet. Since the grass was low in $\mathrm{N}$ and the apparent digestibility was also low, it is possible that protein supplementation with clover may account for a large proportion of the increase.

Joyce \& Newth (1967), Rattray \& Joyce (1969) and Ulyatt (197r), showed that the efficiency of utilization of digested energy was greater for clover diets than for grass. The results in Table 3 show a marked increase in the live-weight gain/unit of digestible energy consumed for the all-clover diet compared with the all-grass and grassconcentrate diets. Although the difference was not quite significant $(P<0.05)$, the utilization of the hay-clover mixture was $27 \%$ and $21 \%$ higher than those for diets 3 and 4 respectively, but was similar to that for diet 5 . This might indicate that the apparently low-quality clover supplement was comparable in terms of animal response to the high-energy protein and mineral supplement of diet 5 .

The causes of the differences in the efficiency of food utilization between clover and grass have been discussed by a number of authors. Johns et al. (1963), Milford \& Minson (1965, 1966) and Grimes et al. (1967) considered that the change in molar proportions of rumen volatile fatty acids were implicated in the differences in utilization of pasture species, but Ulyatt (1969, I97I) and Weston \& Hogan (1971) argued that the small differences obtained were nutritionally insignificant. The present work shows that the changes in molar proportions of rumen VFA were very small and insignificant, and would be unlikely to contribute to any differences in food utilization. 
The largest change in the pattern of fermentation was recorded for diets 4 and 5 in which groundnut meal was included, where there was a shift of fermentation from acetate to butyrate production. Yet, despite this change in the pattern of fermentation, the liveweight gain/unit of digestible energy for diet 2 was $21 \%$ greater than that for diet 4 and similar to that for diet 5 .

The chemical and physical analysis showed there was a greater intake of readily fermentable carbohydrate and $\mathrm{N}$ with the clover diets than with grass alone. There was also a greater intake of readily fermentable carbohydrate with the barley supplement in diet 3 and of carbohydrate and $\mathrm{N}$ with the barley and groundnut supplement of diet 4 , and these produced corresponding increments of live-weight gain and efficiency of food utilization. However, the results suggest that this in itself may not have supported the levels of weight gain/unit of digestible energy consumed that was achieved with the clover supplement in diet 2 . With diet 5 the supplement intake and composition in terms of readily fermentable carbohydrate, $\mathrm{N}$ and minerals was essentially similar to that of the clover supplement of diet 2, and as shown in Table 3, live-weight gain/unit of digestible energy was also similar.

It appears from these results that the efficacy of clover in promoting increased efficiency of utilization of digested energy lies mainly in its ability to supply a high level of readily digested energy, $\mathrm{N}$ and minerals in proportions which are favourable to ruminant digestion.

Thanks are due to Professor P. T. Thomas CBE, Director of the Welsh Plant Breeding Station, for facilities to carry out this work. I am also grateful to $\mathrm{Mr}$ J. R. Jones for his assistance throughout the experiments and for his care of experimental animals, to Mr T. A. Thomas and to the Staff of the Chemistry department for mineral analyses, and to Dr D. I. H. Jones for his helpful discussions in the preparation of this paper.

\section{REFERENCES}

Agricultural Research Council (1965). The Nutrient Requirements of Farm Livestock No. 2, Ruminants. London: Agricultural Research Council.

Bailey, R. W. (1964). N.Z. Fl agric. Res. 7, 496.

Cavell, A. J. (1955). F. Sci. Fd Agric. 6, 479.

Evans, P. S. (r964). N.Z. Fl agric. Res. 7, 508.

Grimes, R. C., Watkin, B. R. \& Gallagher, J. R. (r967). F. agric. Sci., Camb. 68, I I.

Johns, A. T., Ulyatt, M. J. \& Glenday, A. C. (I963). F. agric. Sci., Camb. 6r, 20 I.

Joyce, J. P. \& Newth, R. P. (1967). Proc. N.Z. Soc. Anim. Prod. 27, 166.

Lancashire, J. (1971). Ir. F. agric, Res. ro, 103.

Miles, D. G., Walters, R. J. K. \& Evans, E. M. (ı g69). Anim. Prod. I1, 19.

Milford, R. \& Minson, D. G. (1965). Br. F. Nutr. 19, 373.

Milford, R. \& Minson, D. G. (1966). F. Br. Grassld Soc. $21,7$.

Nijkamp, H. J. (1965). In Energy metabolism [K. L. Blaxter, editor]. London and New York: Academic Press.

Patil, B. D. (1969). Genetic variation in herbage species with respect to animal performance. Ph.D. Thesis, University of Wales.

Rattray, P. V. \& Joyce, J. P. (1969). Proc. N.Z. Soc. Anim. Prod. 29, 102.

Rattray, P. V. \& Joyce, J. P. (1970a). N.Z. $\mathscr{l}$ l agric. Res. 13, 778.

Rattray, P. V. \& Joyce, J. P. (1970b). N.Z. Fl agric. Res. 13, 792.

Rattray, P. V. \& Joyce, J. P. (1970c). N.Z. Yl agric. Res. 13, 800.

Sinclair, D. P., Clarke, A. E. \& Filmer, D. B. (1956). Proc. N.Z. Soc. Anim. Prod. 16, 23. 
Tilley, J. M. A. \& 'Terry, E. A. (1963). F. Br. Grassld Soc. 18, 104. Ulyatt, M. J. (г969). Proc. N.Z. Soc. Anim. Prod. 29, 114.

Ulyatt, M. J. (197r). N.Z. Fl agric. Res. 14, 352.

van Soest, P. J. (1963). F. Anim. Sci. 22, 838 .

Weston, R. H. \& Hogan, J. P. (1971). Aust. F. agric. Res. 22, 139. 